\title{
EXPERIMENTAL DEGENERATION OF THE RETINA
}

\author{
II. THE LESION PRODUCED BY BROMOACETATE: \\ OPHTHALMOSCOPIC AND HISTOLOGICAL FEATURES* \\ BY \\ D. R. LUCAS, $\uparrow$ J. P. NEWHOUSE $\uparrow$ AND J. B. 'DAVEY
}

Ophthalmological Research Department, Royal College of Surgeons

During the course of an investigation of the effects of various thiol reagents upon the rabbit retina (Sorsby, Newhouse, and Lucas, 1957) it was observed that sodium bromoacetate caused histological damage, the details of which are recorded here.

Twelve adult rabbits of mixed stock weighing 1.5 to $2.5 \mathrm{~kg}$. received intravenous injections of from 16 to $32 \mathrm{mg}$. $/ \mathrm{kg}$. sodium bromoacetate. In three animals the dose was repeated on the following day. The nine survivors were killed for histological examination 3 to 21 days after injection.

Two animals received combined injections of sodium bromoacetate $(16 \mathrm{mg} . / \mathrm{kg}$.) and sodium iodoacetate $(16 \mathrm{mg}$. $/ \mathrm{kg}$.) and were killed 7 days later. All doses are quoted in terms of sodium salt.

The solutions for injection were prepared immediately before use by neutralizing the free acid and making up to volume with phosphate buffer. The eyes were fixed in acid Zenker's solution immediately after death. After removal of the lens, paraffin sections were cut and stained by ordinary haematoxylin and eosin, and by Mallory's phosphotungstic acid haematoxylin.

\section{Ophthalmoscopic Findings}

\section{Observations}

Retinal haze, probably due to oedema, was usually observed on the day after injection of doses of $32 \mathrm{mg} . / \mathrm{kg}$.; 2 days later, this effect had diminished and faint pigment clumping was apparent. By 10 days after injection, the pigmentary disturbance in the mid-ventral region had assumed a cobblestonelike appearance; the central fundus showed many yellow spots, but the area above the disc appeared almost normal. No further changes were observed a week later. After the mixtures of iodoacetate and bromoacetate the appearances were similar.

\section{Histological Findings}

(i) After single doses of $16-23 \mathrm{mg} . / \mathrm{kg}$. of bromoacetate, three rabbits showed no retinal damage.

(ii) After two injections of $23 \mathrm{mg} . / \mathrm{kg}$. of bromoacetate, one rabbit showed a very localized loss of visual cells in the area centralis when examined a

* Received for publication January 12, 1957.

$\dagger$ Member of the Wernher Group for Research in Ophthalmological Genetics (Medical Research Council). 
week after the second injection. A few pyknotic rod nuclei remained and Müller fibres were seen entering the damaged area. The inner layers were unaffected in this animal.

(iii) After single doses of $32 \mathrm{mg} . / \mathrm{kg}$. of bromoacetate, five rabbits showed severe retinal damage. In one of these animals, killed three days after injection, many visual cell nuclei were pyknotic and the rods were disintegrated in the area centralis. Numbers of Müller fibres undergoing mitosis were observed in both inner and outer nuclear layers. Occasional pyknotic ganglion cells were seen, and a few bipolar cells were also pyknotic (Fig. 1).

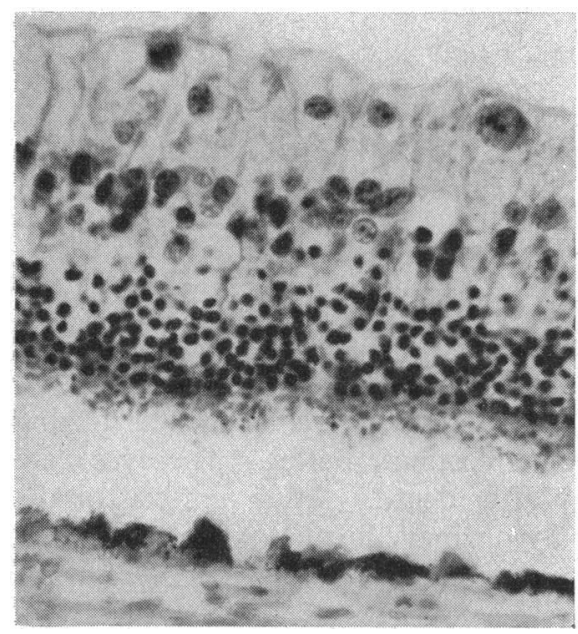

Fig. 1.-Area centralis 3 days after intravenous injection of $32 \mathrm{mg} . / \mathrm{kg}$. bromoacetate, showing disintegration and pyknosis of the visual cells and scattered pyknotic nuclei in the bipolar layer. Phosphotungstic acid haematoxylin $\times 400$.

In the right eye, a few visual cells in the mid-dorsal region were also pyknotic. In the other four severely affected animals, killed 7-21 days after injection, very few pyknotic visual cells remained and all layers of the retina had largely disappeared over much of the area centralis (Fig. 4, opposite). The pigmented epithelium was involved in only two animals; continuity was lost and the cells had become entangled amongst the Müller fibre proliferations (Fig. 5, opposite). In three animals there was a small area of necrosis in the visual cell layer of the mid-dorsal region (Fig. 3, opposite). In one animal, foci of lymphocytic infiltration were seen on the choroid.

(iv) After the combined injections of $16 \mathrm{mg}$. each of iodoacetate and bromoacetate, both rabbits showed considerable retinal damage although similar doses of the substances given individually could have been expected to cause, at most, only very mild lesions. In one of the animals, the lesion was both extensive and severe, in the other it was more localized. In the former the pigmented epithelium was extensively involved and infiltrates of lymphocytes were seen in the choroid. 
(2)
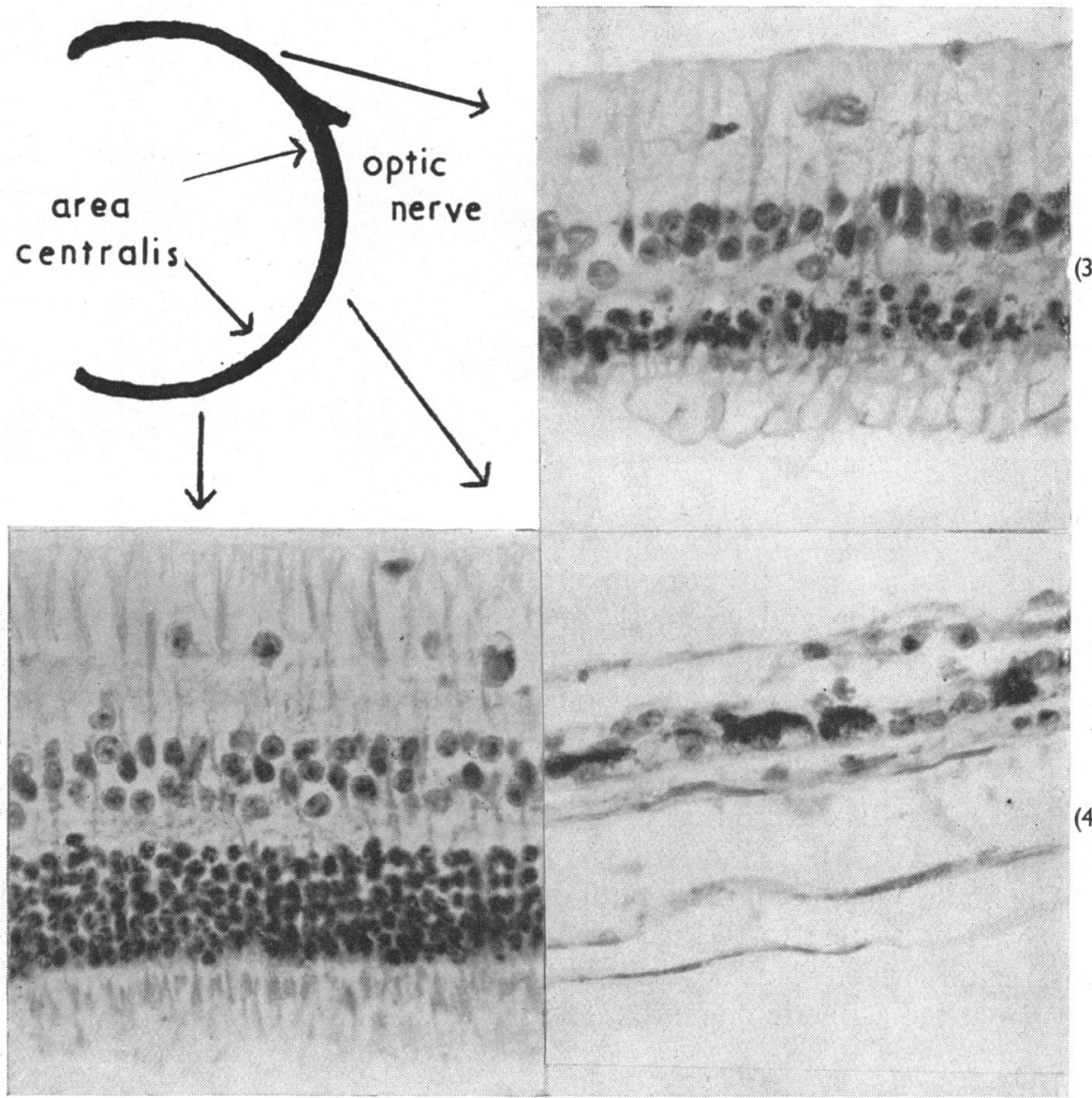

FIGs 2-4.-Mid-dorsal region, area centralis, and peripheral region of one eye (indicated in diagram) showing respectively no changes, slight damage to visual cell layer, and total destruction of the retina 7 days after injection of $32 \mathrm{mg} . / \mathrm{kg}$. bromoacetate. Haematoxylin and eosin $\times 400$.

Fig. 5.-Mid-ventral region, showing proliferation of Müller fibres in a damaged area with breaking up and entanglement of pigmented epithelium 16 days after injection of $32 \mathrm{mg} . / \mathrm{kg}$. bromoacetate. Phosphotungstic acid haematoxylin $\times 400$.

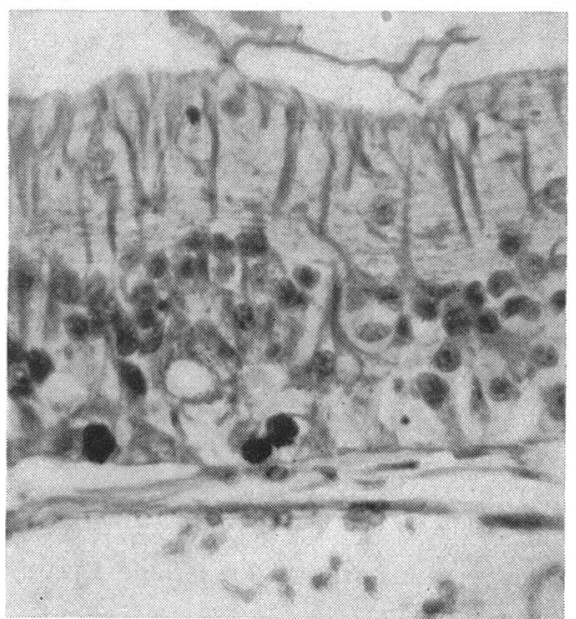




\section{Discussion}

Sodium bromoacetate has not previously been known to damage the rabbit retina. Ophthalmoscopically, the effects are essentially similar to those which follow administration of iodoacetate (de Berardinis, 1953). The histological features of the lesion closely resemble those associated with iodoacetate (Noell, 1952, 1953; Schubert and Bornschein, 1951; Karli, 1952, 1954; de Berardinis, 1953). The main difference is that bromoacetate affects a more limited area of the retina. Although the visual cells appear to be the most susceptible, the other layers in the area centralis are also usually demolished. Since this damage was evident within 7 days of injection, it appears to be a direct effect of the drug and not a late secondary atrophy consequent upon damage to the pigmentary epithelium, as suggested by Noell $(1952,1953)$ in the case of iodoacetate.

Both bromoacetate and iodoacetate react with thiol compounds, such as glutathione, in vitro; in work in progress they have both been shown to inhibit respiration and glycolysis of the isolated retina to a similar extent and the addition of a thiol-donor can reverse some of these effects. The histological resemblances are parallel to the biochemical findings: both agents produce a similar lesion and when given together the effects are additive.

On a molar basis, bromoacetate is somewhat less lethal than iodoacetate and also less destructive to retina.

The finding that damage by both drugs is most severe in the area centralis may well be related to the special functional and metabolic importance of this region, which is also selectively injured in the rabbit by exposure to oxygen at atmospheric pressure (Noell, 1955).

\section{Summary}

(1) The intravenous injection of $32 \mathrm{mg}$. $/ \mathrm{kg}$. sodium bromoacetate results in necrosis of the area centralis of the rabbit retina.

(2) The histological findings resemble those previously reported after injection of sodium iodoacetate, but the damage is more localized.

We are indebted to Mrs D. B. Hatton for technical assistance.

\section{REFERENCES}

BERARDINIS, E. de (1953). Rass. ital. Ottal., 22, 345.

KARLI, P. (1952). Arch. Anat. (Strasbourg), 35, 1.

(1954). Ophthalmologica (Basel), 128, 137.

NoEld, W. K. (1952). J. cell. comp. Physiol., 40, 25.

- (1953). "Studies on the Electrophysiology and the Metabolism of the Retina." United States Air Force School of Aviation Medicine. Randolph Field, Texas. Project No. 21-1201-0004. Report No. 1 .

(1955) Amer. J. Ophthal., 40, No. 5, pt. 2, 60.

SCHUBERT, G., and BORNSCHEIN, H. (1951). Experientia (Basel), 7, 461.

SORSBY, A., NEWHOUSE, J. P., and LuCAS, D. R. (1957). British Journal of Ophthalmology, 41, 309. 